\title{
Antibacterial performance of bovine lactoferrin-fish gelatine electrospun membranes
}

\author{
Jorge Padrão $^{\mathrm{a}}$, Raul Machado ${ }^{\mathrm{b}}$, Margarida Casal ${ }^{\mathrm{b}}$, Senentxu Lanceros-Méndez ${ }^{\mathrm{c}}$, \\ Ligia R. Rodrigues ${ }^{a}$, Fernando Dourado ${ }^{a}$, Vitor Sencadas ${ }^{\mathrm{d}, *}$ \\ a Centre of Biological Engineering, University of Minho, 4710-057 Braga, Portugal \\ ${ }^{\mathrm{b}}$ Centre of Molecular and Environmental Biology (CBMA), Department of Biology, University of Minho, 4710-057 Braga, Portugal

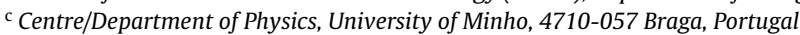 \\ d School of Mechanical, Materials and Mechatronics Engineering, University of Wollongong, Wollongong, NSW 2522, Australia
}

\section{A R T I C L E I N F O}

\section{Article history:}

Received 5 February 2015

Received in revised form 20 August 2015

Accepted 21 August 2015

Available online 24 August 2015

\section{Keywords:}

Electrospinning

Fish gelatine

Bovine lactoferrin membranes

Bactericidal

Proteins

\begin{abstract}
A B S T R A C T
The increase of antibiotic resistant microorganisms urged the development and synthesis of novel antimicrobial biomaterials to be employed in a broad range of applications, ranging from food packaging to medical devices. This work describes the production and characterization of a protein-based electrospun fibrous membranes bearing antimicrobial properties. Its composition is exclusively comprised of proteins, with fish gelatine as structural matrix and bovine lactoferrin (bLF) as the active antimicrobial agent. The bLF bactericidal effect was determined against clinical isolates of Escherichia coli and Staphylococcus aureus through microdilution assays. Two distinctive methods were used to incorporate bLF into the fish gelatine nanofibres: (i) as a filler in the electrospinning formulation with concentrations of 2, 5 and 10 (wt\%), and cross-linked with glutaraldehyde vapour, in order to achieve stability in aqueous solution; and (ii) through adsorption in a solution with $40 \mathrm{mg} \mathrm{mL}^{-1}$ bLF. Fourier transform infrared spectroscopy analysis showed that the structure of both proteins remained intact through the electrospinning blending and cross-linking procedure. Remarkable antibacterial properties were obtained with membranes containing $5 \%$ and $10 \%$ bLF with a bacterial reduction of approximately $90 \%$ and $100 \%$, respectively.
\end{abstract}

(c) 2015 Elsevier B.V. All rights reserved.

\section{Introduction}

Innovative bio-based materials bearing active biological activities are being designed for the development of enhanced commodities. Proteins are biomacromolecules with an overwhelming array of properties and biological activities due to their diverse amino acid composition and architectural conformation [1]. With the adequate engineering processes, proteinaceous byproducts and waste materials such as those derived from the fish processing industry, may be transformed into high value protein-based materials displaying remarkable active properties [2]. Several protein-based polymers are already thoroughly explored and among them, gelatine represents one of the most intensively used worldwide with an increasing demand [3]. Gelatine is easily available, transparent, flexible and resilient, rendering a preferred base material vastly used by food, pharmaceutical, cosmetic and several specialized industries [4,5]. Alternative sources of

\footnotetext{
* Corresponding author.

E-mail address: vsencadas@gmail.com (V. Sencadas).
}

gelatine are being explored to diminish the use of mammalian origin gelatine, due to the reported foodborne transmission of bovine spongiform encephalopathy as well as other prion outbreaks $[5,6]$. Gelatine is produced through the partial denaturation of collagen, one of the most prominent proteins found in mesodermal tissues and is mainly extracted from bones, skins, tendons and hides [7]. The origin and hydrolysis methodologies employed for collagen denaturation renders different gelatines with distinct physical and chemical properties. Gelatine type A and type B are obtained from the acid- and alkali-treated precursors, respectively $[4,7,8]$.

In the fish processing industry, inedible fish constituents such as skin, fins, maws and bones account for approximately $30 \%$ of the processed catch $[8,9]$. In 2014 , these wastes represented nearly 50 million tonnes of the worldwide fishery production [10]. The disposal of these "wastes" represents an increasing environmental and health problem. Fish by-products may be processed into gelatine for the development of added-value products. Gelatine materials are interesting materials for biomedical applications, not only for drug encapsulation in pharmaceutical industry [11] but also for membranes for wound dressings and scaffolds capable to promote biomineralization [12]. 
Cationic proteins and peptides with antimicrobial properties represent a promising response to the emerging threat of antimicrobial resistance since they may synergistically act with, or even substitute antibiotics, that are becoming ineffective [13,14].

Lactoferrin (LF) is an $80 \mathrm{kDa}$ glycoprotein from the innate immune system. An impressive plethora of roles have been attributed to LF including antimicrobial activity against bacteria, virus, yeast and parasitic protozoa, among others $[15,16]$. The mechanism underlying LF antibacterial activity is primarily ascribed to its iron chelating property which prevents the development of pathogenic bacteria, exerting a bacteriostatic effect $[17,18]$. Moreover, LF is able to bind to several bacterial surface components (proteins, lipotheichoic acid, porins, lipids) destabilizing the membrane polarity, hence increasing the permeability and metabolic burden of sensitive bacteria while preventing adhesion and invasion of host cells by a wide scope of bacteria [16,19]. Bovine lactoferrin (bLF), mainly obtained from non-pasteurized milk and cheese whey, is considered to be a safe ingredient in formulations for food, pharmaceutical and cosmetic products, with an increasing worldwide industrial scale production between 80 and 100 tonnes a year $[20,21]$.

Electrospinning is a versatile technique that allows the fabrication of fibres with widths ranging from micro to nanometres. In this process, a strong electrostatic field is applied to a polymer solution held in a syringe and feed through a needle [22]. As the fibre jet travels through the atmosphere between the needle tip to a ground collector, the solvent evaporates and solid polymer fibres are deposited on the collector [22]. Although gelatine has been successfully electrospun into fibres, the preparation of electrospun membranes raises some critical issues, such as the use of highly toxic solvents such the dissolution of the protein in acetic acid/formic acid mixtures [23], 1,1,1,3,3,3-hexafluoro-2propanol [24], 2,2,2-trifluoroethanol [25] and with acetic acid and ethyl acetate aqueous solutions [26].

The Gram-negative Escherichia coli is a facultative anaerobe, widely known to be one of the major gastrointestinal microflora entities, but also a resourceful pathogenic [27]. The Gram-positive rod shape Staphylococcus aureus is a commensal organism present in the human skin and mucosal and is prolific in virulence factors and antimicrobial resistance [28]. Moreover, these microorganisms were positively identified as etiological agents of foodborne illness [29].

The major constituents of bacteria cell envelope are the anionic phosphatidylglycerol, and zwitterion phosphatidylethanolanine, thus the overall bacteria cytosol membrane charge is negative [30-32]. bLF antimicrobial motifs are mainly found in its $\mathrm{N}$ terminal, rich in cationic and hydrophobic amino acid residues, which are prone to exert the destabilization of the bacteria cell envelope through its lethal depolarization $[15,31,32]$. In the case of the Gram-negative bacteria, the lipopolysaccharide (LPS) envelope may be additionally disrupted by the action of the bLF LPS binding loop and/or by the $\mathrm{Ca}^{2+}$ chelation by the sialic acid groups present in the bLF glycan moiety, since $\mathrm{Ca}^{2+}$ is essential for the stabilization of the inner core of LPS [33,34]. Further, the bLF may exert a bacteriostatic activity due to its potent iron binding capacity that may deprive the environment of this essential micronutrient, blocking several essential biochemical reactions $[17,18]$.

In the last decade, several composite materials were developed for antimicrobial applications. Nevertheless, these systems were based in active pharmaceutical drugs $[35,36]$ or metallic nanoparticles, being silver nanoparticles one of the most common materials used for the aforementioned application [37-39]. Concerning the use of metallic nanoparticles, several safety concerns have being raised due to potential cytotoxicity effect in cells [40], which makes urgent the need to pursuit more natural and compatible materials for antimicrobial applications, especially if the main applications is for food packaging.

There is a lack of work concerning the blends of fish gelatine with bLF to promote novel nanoparticle metal free antimicrobial membranes. In the present work, gelatine fibrous membranes containing different amounts of bLF were produced by electrospinning and tested for their antimicrobial performance. The influence of the filler on fibre diameter and average size distribution was characterized. The bactericidal performance of electrospun gelatine/bLF membrane composites and gelatine fibre mats with adsorbed bLF was assessed by contact killing against the Gram-negative bacteria E. coli and the Gram-positive S. aureus.

\section{Experimental procedures}

\subsection{Materials}

Bovine lactoferrin (bLF) was obtained from DMV International (USA) with a reported composition (\% dry weight) of 96\% protein, $0.5 \%$ ash and $3.5 \%$ moisture, and an iron content of $\sim 120 \mathrm{ppm}$. Fish gelatine (FG) and formic acid (FA) were purchased from Sigma-Aldrich and N,N-dimethylformamide (DMF) was acquired from Merck. The polymer solution was prepared as described elsewhere [41]. Briefly, fish gelatine was dissolved in a mixture of FA and $\operatorname{DMF}(4: 6 \mathrm{v} / \mathrm{v})$ at $50^{\circ} \mathrm{C}$ to achieve a final gelatine concentration of $30 \mathrm{wt} \%$. For the preparation of gelatine/bLF composites with different bLF contents $(0,2,5$ and $10 \mathrm{wt} \%)$, the filler was dispersed in the FA/DMF solution with the help of an ultrasound bath (Bandelin, Sonorex Super RK 106) for $4 \mathrm{~h}$, at room temperature. Afterwards, gelatine was added to the solution and placed under agitation at $50^{\circ} \mathrm{C}$.

\subsection{Electrospinning}

The protein solution was placed in a commercial plastic syringe $(10 \mathrm{~mL})$ fitted with a steel needle with $500 \mu \mathrm{m}$ of inner diameter. Electrospinning was conducted at $1.25 \mathrm{kV} \mathrm{cm}^{-1}$ (distance to collector of $20 \mathrm{~cm}$ ) with a high voltage power supply from Glassman (model PS/FC30P04). A syringe pump (Syringepump) was used to feed the solutions into the needle tip at $0.2 \mathrm{~mL} \mathrm{~h}^{-1}$. The generated electrospun mats were collected in grounded metal collecting plates. After processing, the membranes were stored at room temperature in a desiccator with silica gel, protected from light, until further use.

\subsection{Cross-linking and determination of the degree of cross-linking}

Electrospun fibre mats were placed in a vapour chamber (vacuum-temp, JPSelecta) containing $20 \mathrm{~mL}$ of glutaraldehyde (GA, $50 \%$ PS, Panreac). The fibre mats were exposed to GA-saturated air for $48 \mathrm{~h}$ at room temperature $\left(25^{\circ} \mathrm{C}\right)$. Unreacted GA aldehyde groups were neutralized by immersion in $100 \mathrm{mM}$ (glycine concentration) for $30 \mathrm{~min}$ at $\mathrm{pH} 7$ and thoroughly washed with sterilized deionized water [42]. Finally, the membranes were freeze-dried (Scanvac CoolSafe VP100) for at least $24 \mathrm{~h}$. To obtain electrospun mats with adsorbed bLF, pristine cross-linked gelatine fibre membranes were cut into $9 \mathrm{~mm}$ diameter disks and immersed in $40 \mathrm{mg} \mathrm{mL}^{-1}$ bLF aqueous solution for $24 \mathrm{~h}$ at $25^{\circ} \mathrm{C}$, under mild orbital agitation. The disks were then retrieved from the solution and freeze-dried (Scanvac CoolSafe VP100) for at least $24 \mathrm{~h}$ and then stored until further use in the subsequent assays. After the period of immersion the electrospun mats in the $40 \mathrm{mg} \mathrm{mL}^{-1}$ bLF solution, the bLF solution was freeze-dried (Scanvac CoolSafe VP100) for at least $96 \mathrm{~h}$. Immediately afterwards the obtained mass of bLF, 
not absorbed by the mats was quantified, and the concentration of adsorbed bLF was estimated.

The degree of cross-linking of fish gelatine electrospun fibres with and without bLF was determined by ninhydrin (NHN) assay. NHN reacts with free amino groups to produce the purple coloured amino complex, whose optical density is proportional to the number of free amino groups [43-45].

NHS solution was prepared as follows: solution A: $1.05 \mathrm{~g}$ of citric acid, $10 \mathrm{~mL}(1.0 \mathrm{M}) \mathrm{NaOH}$ and $0.04 \mathrm{~g} \mathrm{SNCl} 2 \cdot 2 \mathrm{H}_{2} \mathrm{O}$ were mixed and the volume filled to $25 \mathrm{~mL}$ with deionized water; solution $\mathrm{B}: 1.00 \mathrm{~g}$ ninhydrin was added to $25 \mathrm{~mL}$ of ethylene glycol monomethyl ether and stirred at room temperature until complete dissolution. The two solutions, A and B, were mixed and stirred at room temperature for $45 \mathrm{~min}$ and stored in a dark bottle. The degree of cross-linking was assessed in $1.5 \mathrm{mg}$ of lyophilized electrospun gelatine membranes with and without bLF. The fibre mats were incubated with $1 \mathrm{~mL}$ of ninhydrin solution and heated to $100^{\circ} \mathrm{C}$ in a water bath for $20 \mathrm{~min}$. Next, the solution was cooled down to room temperature, diluted with $5 \mathrm{~mL}$ of $50 \%$ isopropanol, and the optical absorbance was measured at $570 \mathrm{~nm}$ with a spectrophotometer (UV, 2501 PC Shimadzu). The amount of free $\mathrm{NH}_{2}$ groups in the sample was determined by comparison to a standard curve of glycine vs absorbance. The degree of cross-linking $\left(X_{C L}\right)$ is determined according to Eq. (1):

$X_{C L}=\frac{\left[(N H N \text { reactive } \text { a min } e)_{\text {free }}-(\text { NHN reactive a min } e)_{f i x e d}\right]}{(\text { NHN reactive a min } e)_{f r e s h}}$

$\times 100$

where "free" is the mole fraction of free $\mathrm{NH}_{2}$ in the non-cross-linked samples and "fixed" is the mole fraction of free $\mathrm{NH}_{2}$ remaining in the cross-linked samples. Five different regions of each type of electrospun samples were evaluated.

\subsection{Characterization of electrospun fibre mats}

Electrospun samples were coated with a thin gold layer using a sputter coater (Polaron, model SC502) and their morphology was analysed by scanning electron microscopy (SEM, Leica Cambridge) with an accelerating voltage of $15 \mathrm{kV}$. The nanofibre average diameter and distribution were calculated with approximately 50 randomly selected fibres with ImageJ image processing software [46]. Fourier transform infrared (FTIR) spectra were acquired at room temperature with an Alpha FTIR (Bruker) in attenuated total reflectance (ATR) mode from 4000 to $600 \mathrm{~cm}^{-1}$. FTIR spectra were collected after 32 scans with a resolution of $4 \mathrm{~cm}^{-1}$.

\subsection{Minimal inhibitory concentration (MIC) of bLF}

The antimicrobial performance of bLF against clinical samples of $E$. coli and $S$. aureus (kindly provided by the Faculty of Pharmacy, University of Porto, Portugal) was determined using broth microdilution tests. Bacterial pre-cultures were prepared in $20 \mathrm{~mL}$ of Nutrient Broth (NB, Himedia) with a volume ratio of 1:5 and incubated overnight at $37^{\circ} \mathrm{C}$ and $120 \mathrm{rpm}$. Bacterial cell suspensions $1.5 \times 10^{6} \mathrm{CFU} \mathrm{mL}^{-1}$, diluted in phosphate buffered saline(PBS, $\mathrm{NaCl} 8 \mathrm{~g}, \mathrm{KCl} 0.2 \mathrm{~g}, \mathrm{Na}_{2} \mathrm{HPO}_{4} 1.44 \mathrm{~g}, \mathrm{KH}_{2} \mathrm{PO}_{4} 0.24 \mathrm{~g}$, per litre, $\mathrm{pH}$ 7.4) were inoculated in $200 \mu \mathrm{L}$ of NB containing bLF concentrations ranging from 0.0 to $40.0 \mathrm{mg} \mathrm{mL}^{-1}$ for $24 \mathrm{~h}$, at $37^{\circ} \mathrm{C}$ and $120 \mathrm{rpm}$. The optical density at $600 \mathrm{~nm}$ was measured and the MIC assessed, using 6 replicas of each bacteria and concentration.

\subsection{Evaluation of contact bactericidal effectiveness (contact killing) of the processed electrospun fibre mats}

An adaptation of the AATCC Test Method 100-2012 [47] was used to access the contact bactericidal efficiency of the electrospun fibre mats. Briefly, a pre-culture of each bacterium was prepared in $20 \mathrm{~mL}$ of NB with a volume ratio of $1: 5$ and incubated overnight at $37^{\circ} \mathrm{C}$ and $120 \mathrm{rpm}$. Electrospun samples with $9 \mathrm{~mm}$ diameter were inoculated with $10 \mu \mathrm{L}$ of cell suspension (diluted in PBS) at a concentration of $9.6 \times 10^{5} \mathrm{CFU} \mathrm{mL}^{-1}$ for E. coli and $1.1 \times 10^{6} \mathrm{CFU} \mathrm{mL}^{-1}$ for $S$. aureus, followed by incubation at $37^{\circ} \mathrm{C}$ for $2 \mathrm{~h}$. After incubation, $500 \mu \mathrm{L}$ of PBS were added and carefully stirred for at least 1 min. Finally, the samples were submitted to successive serial dilutions and plated in Mueller Hinton ( $\mathrm{MH}$, Himedia) agar plates, and incubated for $24 \mathrm{~h}$ at $37^{\circ} \mathrm{C}$. The contact killing assays were performed using at least 4 replicas for each bacterium.

\subsection{Statistical analysis}

Statistically significant differences were identified using oneway ANOVA and post hoc Tuckey's multiple comparison as post-test $(p<0.05)$. The statistical results were obtained using GraphPad Prism software (version 5.0) and an alpha value of 0.05 as the significance criterion.

\section{Results and discussion}

\subsection{Characterization of electrospun fibre mats}

Despite the apparent simplicity of the electrospinning process, the morphology/structure of the spun fibres is highly affected by several experimental parameters such as the applied voltage, the collector nature, as well as by a wide range of solution properties namely concentration, conductivity, viscosity, surface tension, and solvent volatility [48]. In this work, the morphology and size distribution of cross-linked electrospun fibres were found to be largely affected by the bLF content. Indeed, while fish gelatine fibres were non-defective with a smooth surface, the increasing concentration of bLF in the spinning solution led to the production of defective fibres (Fig. 1). At 2 wt\%, the electrospun fibre morphology was very similar to neat gelatine. Increasing bLF content to $5 \mathrm{wt} \%$ and $10 \mathrm{wt} \%$ led to the formation of beaded fibres (Fig. 1c), the presence of such defects being more pronounced at the highest bLF contents (Fig. 1d). Under the experimental conditions, the randomly oriented fish gelatine membranes presented an average fibre diameter of $196 \pm 54 \mathrm{~nm}$ that decreased with increasing bLF concentrations (Fig. 1e) down to a minimum of $91 \pm 30 \mathrm{~nm}$ for the samples containing $10 \mathrm{wt} \%$ bLF. This decrease suggested that the critical electric field needed for a stable Taylor cone formation and the subsequent polymer jet are influenced by the presence of lactoferrin in the solution.

Gelatine is a water soluble material thus as-spun fibre membranes, partially or totally, dissolve when in contact with an aqueous medium or high moisture environments [25]. In order to increase the sample stability to aqueous environments, gelatine fibre mats were exposed to a saturated atmosphere of GA to promote chemical cross-linking of the material. It was found that this chemical treatment did not influence the fibre average diameter for an exposure time up to $48 \mathrm{~h}$ and the cross-linked fibres showed the same visual appearance as the as-spun ones [49]. The degree of cross-linking of the gelatine electrospun membranes was determined by the ninhydrin assay. The results showed a degree of cross-linking ranging from 78 to $84 \%$ (Fig. 2), independently of the bLF content. Therefore, it can be assumed that GA is a favourable cross-linking reagent for gelatine electrospun membranes, as it can 

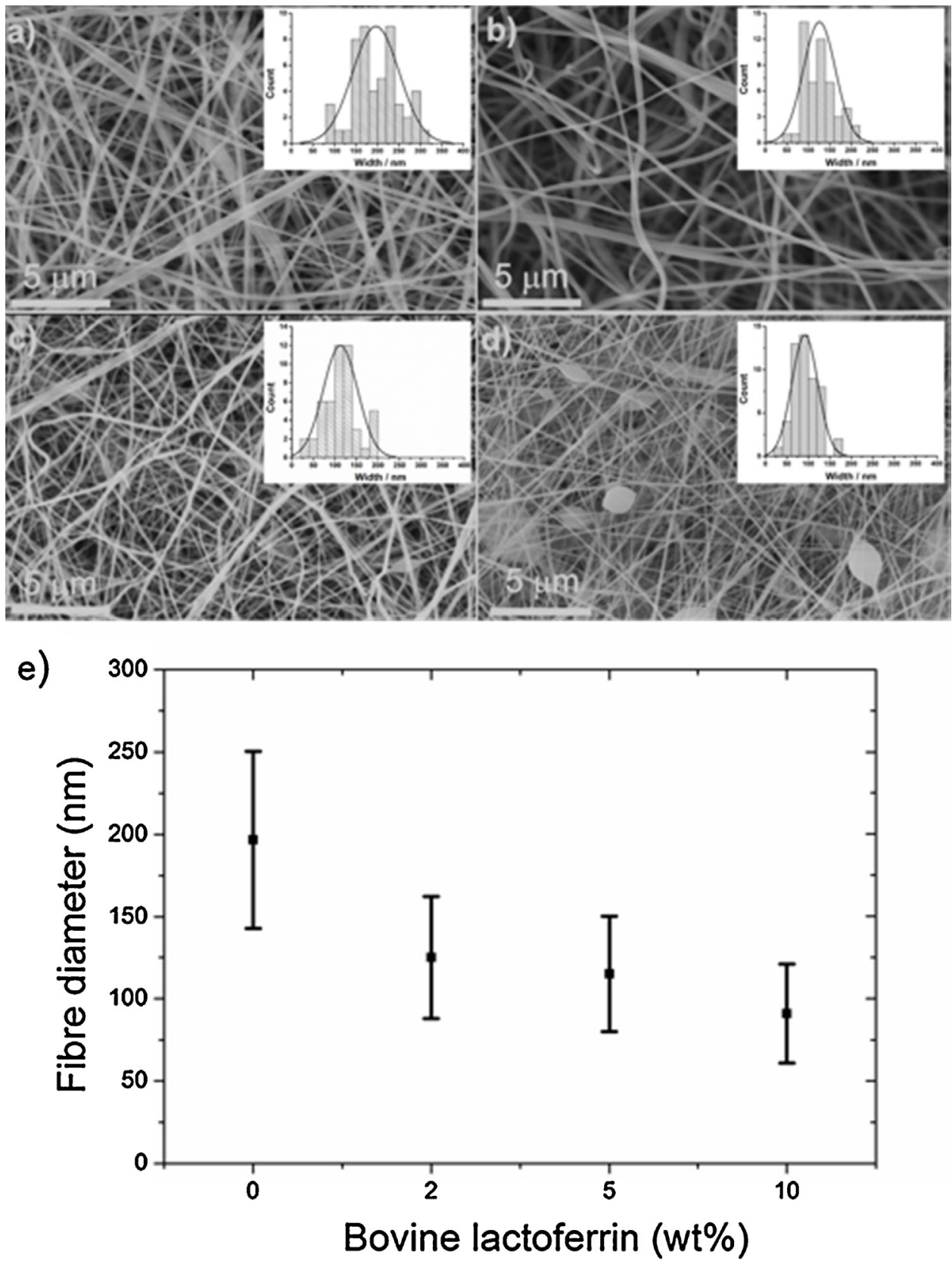

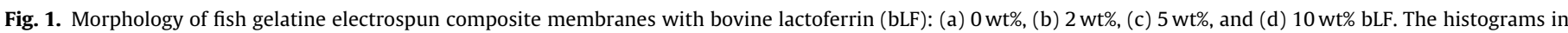

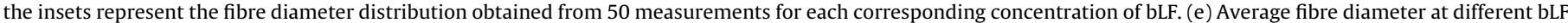
concentrations. Results correspond to the average of three independent assays \pm standard error.

efficiently cross-link protein amino groups. Chemical cross-linking of gelatine with GA involves the reaction of $\varepsilon$-amino groups of lysine or arginine of the polypeptide chain with aldehyde groups of the cross-linking agent by a Schiff base reaction [50]. Moreover, cross-linking is typically associated to a colour change from white to pale yellow [25]. These colour changes have been attributed to the formation of aldimine linkages $(-\mathrm{CH}=\mathrm{N}-$ ) between the free amino acids of lysine or hydroxylysine amino acids residues of the protein and the aldehyde groups of GA [41,51].

The infrared spectrum of lyophilized and electrospun pristine gelatine, as well as fibre mats with bLF, are shown in Fig. 3. All samples exhibit the characteristic amide absorption bands of the peptide group namely, amide I at $1636 \mathrm{~cm}^{-1}$ ( $C=\mathrm{O}$ stretching vibration), amide II at $1514 \mathrm{~cm}^{-1}(\mathrm{~N}-\mathrm{H}$ bending with contribution of $\mathrm{C}-\mathrm{N}$ stretching vibrations) and amide III at $1234 \mathrm{~cm}^{-1}$ (assigned to
$\mathrm{N}-\mathrm{H}$ bending vibration) [52]. The broad absorption band observed between 3500 and $3100 \mathrm{~cm}^{-1}$ was attributed to the contributions from amide $\mathrm{A}(\mathrm{N}-\mathrm{H}$ stretching vibration) and free water present in the material due to storage at room conditions, that may account to $12 \%$ of total sample weight $[41,52,53]$. The absorption bands at 2850 and $2920 \mathrm{~cm}^{-1}$ are attributed to the $\mathrm{C}-\mathrm{H}$ stretching vibration, corresponding to the symmetric and asymmetric stretching of alkyls chains, respectively, with a minor contribution of symmetric and asymmetric stretching vibration in the $\mathrm{CH}_{3}$ groups at $2873 \mathrm{~cm}^{-1}$ and $2955 \mathrm{~cm}^{-1}$, respectively [54].

The absence of shift in peak positions after addition of bLF to gelatine fibres suggests that both the filler and the matrix did not suffer significant structural changes during polypeptide dissolution and subsequent processing by electrospinning (Fig. 3). Similarly, no differences were found between the spectra of pristine electrospun 


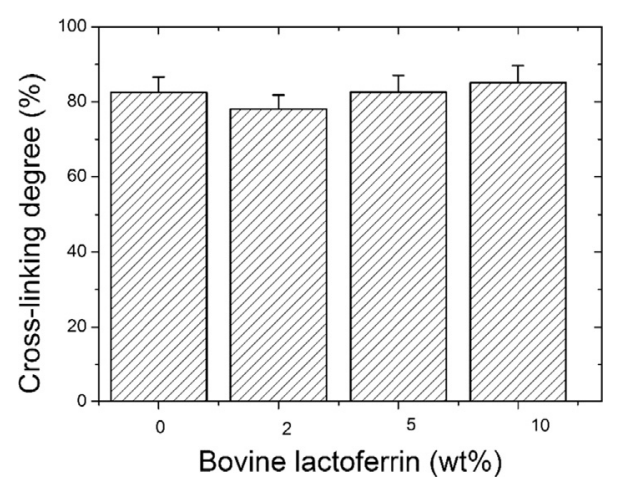

Fig. 2. Degree of cross-linking for gelatine and bLF-gelatine electrospun membranes. Results are expressed as the average of five independent assays \pm the standard error.

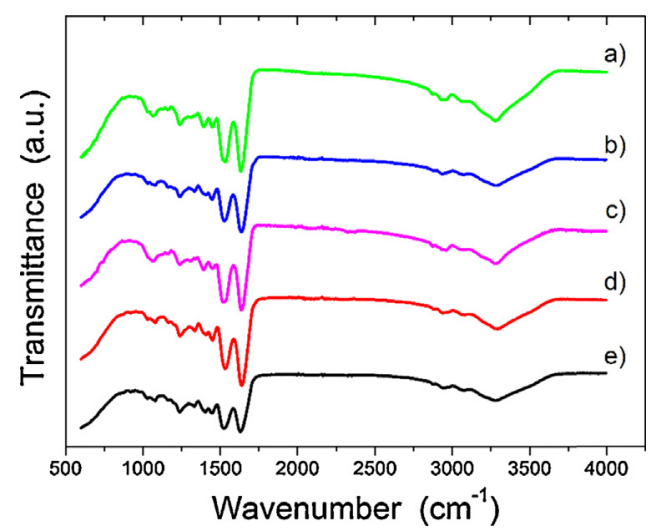

Fig. 3. Attenuated total reflectance Fourier transform infrared (ATR-FTIR) spectra for: (a) gelatine fibre mats with adsorbed bLF, (b) electrospun fish gelatine-bovine lactoferrin $10 \mathrm{wt} \%$ composite, (c) pure bovine lactoferrin, (d) electrospun fish gelatine, and (e) raw fish gelatine.

gelatine membranes and electrospun fibre mats with adsorbed bLF. As both gelatine and LF are proteinaceous materials, the infrared spectra are dominated by the characteristic peaks of the peptide bound.

\subsection{Antibacterial activity - MIC assay}

The antibacterial performance of bLF was evaluated against $E$. coli and S. aureus. The MIC found in the literature for native bovine lactoferrin covers a wide range of values due to different experimental conditions such as cell density of the inoculum, culture media composition and $\mathrm{pH}$, or strains used. Therefore, a key point of the current work was to validate the bLF bactericidal activity by determining the minimal inhibitory concentration (MIC). The MIC value for bLF was found to be $10 \mathrm{mg} \mathrm{mL}^{-1}$ for E. coli with approximately $100 \%$ of bacterial reduction, even though $5 \mathrm{mg} \mathrm{mL}^{-1}$ resulted in $90 \%$ of reduction in the visible growth (Fig. $4 a$ ). At lower concentrations, the effect of bLF in cell growth was minimal with a reduction of only $37 \%$ for $2.5 \mathrm{mg} \mathrm{mL}^{-1}$, and negligible for concentrations below this value (Fig. 4a). These results are in accordance with the work reported by Nonnecke and Smith [55]. As for S. aureus, only the concentration of $40 \mathrm{mg} \mathrm{mL}^{-1}$ was found to be effective in inhibiting cell growth with a reduction of approximately $82 \%$ (Fig. 4b). The bLF bactericidal profile for E. coli suggests an inverse correlation between concentration and growth inhibition, since higher concentrations led to lower visible bacterial growth. Interestingly, this profile was completely different for $S$. aureus and it was not possible to establish a direct correlation between bLF concentration and inhibition of cell growth. For concentrations below a)

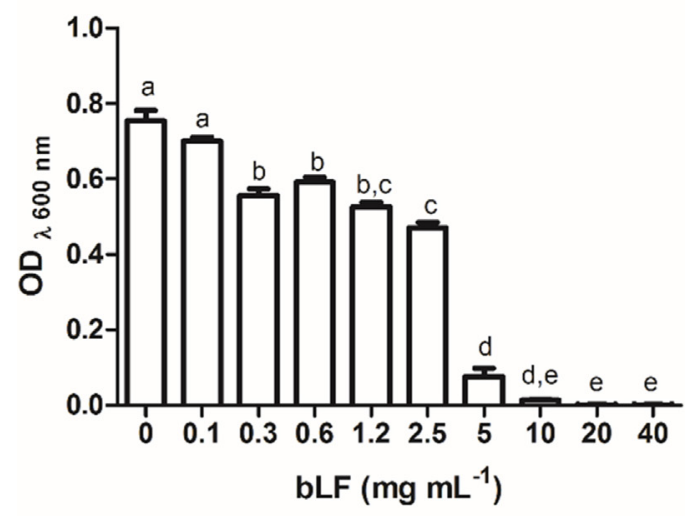

b)

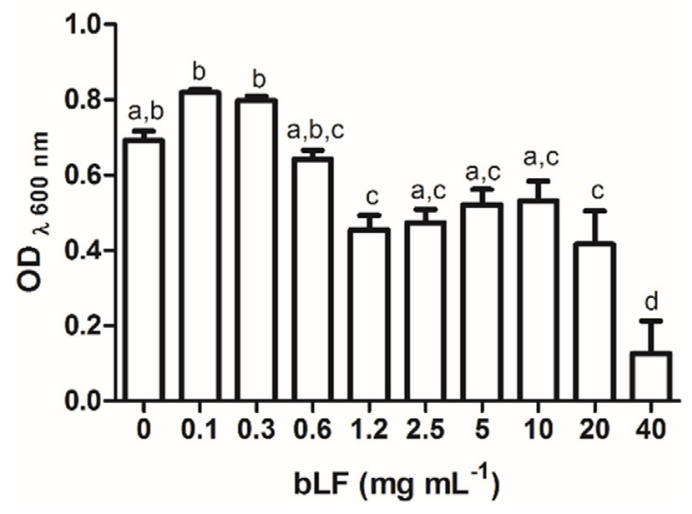

Fig. 4. Bacterial cell growth at $600 \mathrm{~nm}$ for: (a) Escherichia coli and (b) Staphylococcus aureus cultures in nutrient broth (NB) medium supplemented with different bovine lactoferrin concentrations, for $24 \mathrm{~h}$ at $37^{\circ} \mathrm{C}$ in 96 well plates with $120 \mathrm{rpm}$ of orbital agitation. For each bacterium, different letters in the columns denote significant different values of the one-way ANOVA post hoc Tuckey's multiple comparison test $(p<0.05)$. Results are expressed as the average of six independent experiments \pm the standard error.

$0.6 \mathrm{mg} \mathrm{mL}^{-1}$ there was a negligible effect on bacterial cell growth, whereas a minimal inhibitory effect around $30 \%$ was found for concentrations in the range of $1.2-20 \mathrm{mg} \mathrm{mL}^{-1}$.

The fish gelatine composite membranes with different amounts of bLF were evaluated with respect to antibacterial efficiency against E. coli and S. aureus, for $120 \mathrm{~min}$. As shown in Fig. 5, the electrospun fish gelatine mats by itself displayed a considerable bacterial reduction when compared with the inoculum of 2-log, which is probably attributed to the nature of gelatin and was previously observed against $E$. coli [56]. This may be due to the swelling nature of the electrospun mats that do not provide the adequate conditions for bacteria cellular growth. When compared with neat gelatine fibre mats, the membranes containing $2 \mathrm{wt} \%$ and $5 \mathrm{wt} \%$ of bLF exhibited a slight decrease in the number of viable cells, both in E. coli and S. aureus. However, the membranes with $10 \mathrm{wt} \%$ of bLF were highly active against $E$. coli and $S$. aureus, presenting a $6 \log$ reduction (99.9999\% reduction) in the number of CFUs.

To further characterize the mechanism of bLF release and the subsequent antibacterial efficiency, the gelatine fibre mats were immersed in a solution of $40 \mathrm{mg} \mathrm{mL}^{-1}$ of bLF for $24 \mathrm{~h}$. These samples (esFG/bLF) exerted an identical reduction as the ones found for the neat fish gelatine electrospun mats. This can be explained by the low concentration of bLF adsorbed by the membranes which was estimated to be approximately $1.0 \times 10^{-4} \mathrm{mg} \mathrm{mm}^{-2}$. Additionally, the weak bonding between the bLF and the surface of the matrix, 
a)

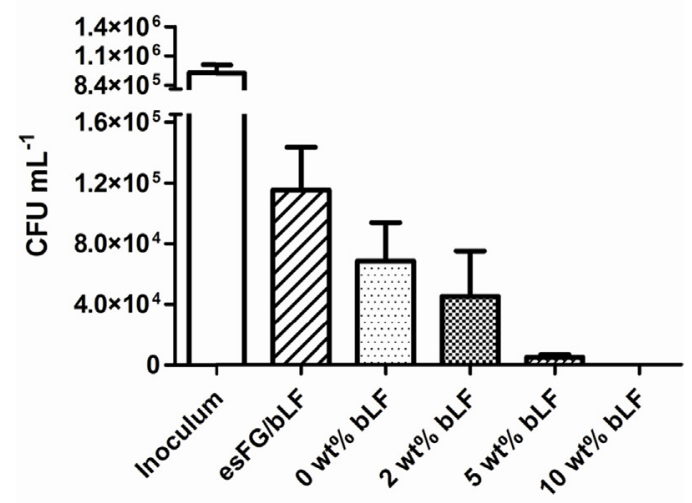

b)

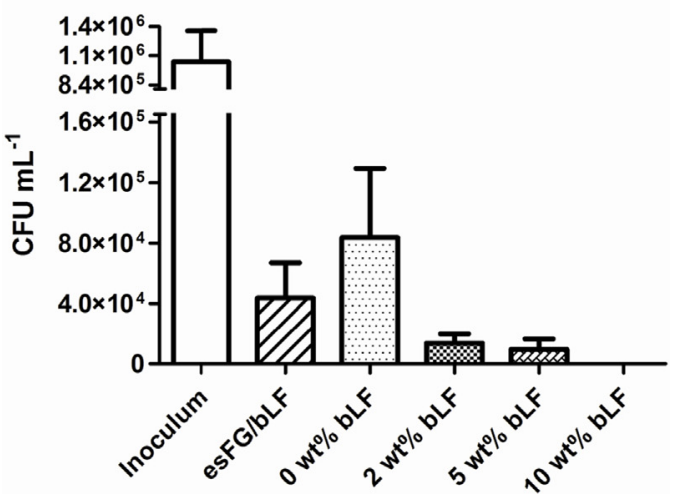

Fig. 5. Colony forming units per $\mathrm{mL}$ of (a) Escherichia coli and (b) Staphylococcus aureus, after $2 \mathrm{~h}$ of contact at $37^{\circ} \mathrm{C}$ with electrospun mats containing different concentrations of $\operatorname{bLF}(0,2,5$ and $10 \mathrm{wt} \%)$ and bLF adsorbed to the surface of the fibres (esFG/bLF). Results are expressed as the average of four independent assays \pm the standard error.

may lead to a fast diffusion of bLF into the culture media. On the other hand, electrospun nanocomposite samples did not seem to hinder the bLF antimicrobial efficiency (Fig. 5).

\section{Conclusions}

This work exploits the potential of sub-products from fish (fish gelatine, FG) and dairy (bovine lactoferrin, bLF) industries for the development of a novel antimicrobial fully protein-based nanocomposite. Fish gelatine was successfully processed into a structural matrix by electrospinning whereas bLF was used as functional antimicrobial filler. Electrospun neat FG fibres shown a mean diameter of $196 \pm 54 \mathrm{~nm}$ and a decrease of the average fibre diameter was observed with the increase of bLF present in polymer solution down to $91 \pm 30 \mathrm{~nm}$, and also leading to the presence of some beads among the membrane.

The bLF MIC values obtained were $10 \mathrm{mg} \mathrm{mL}^{-1}$ for $E$. coli and $>40 \mathrm{mg} \mathrm{mL}^{-1}$ for $S$. aureus. The contact killing efficiency of adsorbed bLF samples was compared to the ones from electrospun FG bearing different concentrations of bLF and it was observed that electrospun samples exhibit a higher killing capacity when compared to the adsorbed bLF. Finally, it was shown that the electrospinning and cross-linking methodology did not affect the bLF bactericidal efficiency against $E$. coli and $S$. aureus. Additionally, this methodology enabled a higher bLF content in the fish gelatine nanofibres which resulted in a $6 \log$ killer efficiency of the films bearing $10 \mathrm{wt} \%$ of bLF.

\section{Acknowledgements}

The authors acknowledge the Portuguese Foundation for Science and Technology (FCT) Strategic Project PEst-OE/EQB/LA0023/ 2013 UID/BIA/04050/2013, UID/BIO/04469/2013, and for the research grants funding through POPH/FSE for JP (SFRH/BD/64901/ 2009) and RM (SFRH-BPD/86470/2012). The authors would also like to thank FEDER funds through the "Programa Operacional Fatores de Competitividade - COMPETE" and by national funds arranged by FCT - Fundação para a Ciência e a Tecnologia, project references PEST-C/FIS/UI607/2014, Matepro - Optimizing Materials and Processes", ref. NORTE-07-0124-FEDER-000037", RECI/BBBEBI/0179/2012 (FCOMP-01-0124-FEDER-027462) and the project "Biolnd - Biotechnology and Bioengineering for improved Industrial and Agro-Food processes", REF. NORTE-07-0124-FEDER-000028, co-funded by the "Programa Operacional Regional do Norte" (ON.2 - O Novo Norte), under the "Quadro de Referência Estratégico Nacional" (QREN), through the "Fundo Europeu de Desenvolvimento Regional" (FEDER). The authors also thank support from the COST Action MP1206 "Electrospun Nano-fibres for bio inspired composite materials and innovative industrial applications". VS thanks the EIS Faculty at UOW for the starting grant.

\section{References}

[1] D. Kaplan, K. McGrath, Protein-Based Materials, Springer Science \& Business Media, 2012.

[2] R.P. Wool, X.S. Sun, Bio-Based Polymers and Composites, 1st ed., Elsevier Academic Press, Burlington, USA, 2005.

[3] M.C. Gómez-Guillén, M. Pérez-Mateos, J. Gómez-Estaca, E. López-Caballero, B. Giménez, P. Montero, Trends Food Sci. Technol. 20 (2009) 3-16.

[4] K.B. Djagny, Z. Wang, S. Xu, Crit. Rev. Food Sci. Nutr. 41 (2001) 481-492.

[5] A.A. Karim, R. Bhat, Food Hydrocoll. 23 (2009) 563-576.

[6] K. Yoshimura, M. Terashima, D. Hozan, T. Ebato, Y. Nomura, Y. Ishii, K. Shirai, J. Agric. Food Chem. 48 (2000) 2023-2027.

[7] S. Ricard-Blum, Cold Spring Harb. Perspect. Biol. 3 (2011) a004978.

[8] J. Wasswa, J. Tang, X. Gu, Food Rev. Int. 23 (2007) 159-174.

[9] F. Shahidi, Proteins from seafood processing discards, in: Z. Sikorski, B. Pan, F. Shahidi (Eds.), Seafood Proteins, Springer, US, 1995, pp. 171-193.

[10] FAO, Food Outlook, Food and Agriculture Organization of the United Nations Rome, 2014.

[11] F. Podczeck, B.E. Jones, Pharmaceutical Capsules, Pharmaceutical Press, 2004

[12] D. Bhatnagar, A.K. Bherwani, M. Simon, M.H. Rafailovich, J. Mater. Chem. B 3 (2015) 5210-5219

[13] L.L. Silver, Clin. Microbiol. Rev. 24 (2011) 71-109.

[14] K. Fukuda, World Health Organization, 2014.

[15] H. Jenssen, R.E.W. Hancock, Biochimie 91 (2009) 19-29.

[16] N.D. Embleton, J.E. Berrington, W. McGuire, C.J. Stewart, S.P. Cummings, Semin. Fetal Neonatal Med. 18 (2013) 143-149.

[17] P.L. Masson, J.F. Heremans, J.J. Prignot, G. Wauters, Thorax 21 (1966) $538-544$

[18] J.D. Oram, B. Reiter, Biochim. Biophys. Acta (BBA): Gen. Subj. 170 (1968) $351-365$.

[19] R.T. Ellison, T.J. Giehl, J. Clin. Invest. 88 (1991) 1080-1091.

[20] H. Wakabayashi, K. Yamauchi, M. Takase, Int. Dairy J. 16 (2006) 1241-1251.

[21] EFSA, EFSA Journal, European Food Safety Authority (EFSA), Parma, 2012, pp. $1-26$.

[22] V. Sencadas, D.M. Correia, C. Ribeiro, S. Moreira, G. Botelho, J.L. Gómez Ribelles, S. Lanceros-Mendez, Polym. Test. 31 (2012) 1062-1069.

[23] T. Balau Mindru, I. Balau Mindru, T. Malutan, V. Tura, J. Optoelectron. Adv. Mater. 9 (2007) 3633-3638.

[24] M. Li, M.J. Mondrinos, M.R. Gandhi, F.K. Ko, A.S. Weiss, P.I. Lelkes, Biomaterials 26 (2005) 5999-6008.

[25] Y.Z. Zhang, J. Venugopal, Z.M. Huang, C.T. Lim, S. Ramakrishna, Polymer 47 (2006) 2911-2917.

[26] J.-H. Song, H.-E. Kim, H.-W. Kim, J. Mater. Sci: Mater. Med. 19 (2008) 95-102.

[27] J.B. Kaper, J.P. Nataro, H.L.T. Mobley, Nat. Rev. Microbiol. 2 (2004) 123-140.

[28] G.Y. Liu, Pediatr. Res, 65 (2009) 71r-77r.

[29] EFSA, EFSA J. 10 (2012) 132.

[30] K. Matsuzaki, Biochim. Biophys. Acta (BBA): Biomembr. 1462 (1999) 1-10.

[31] H.J. Vogel, D.J. Schibli, W. Jing, E.M. Lohmeier-Vogel, R.F. Epand, R.M. Epand, Biochem. Cell Biol. 80 (2002) 49-63.

[32] M. Zasloff, Nature 415 (2002) 389-395.

[33] E. Elass-Rochard, A. Roseanu, D. Legrand, M. Trif, V. Salmon, C. Motas, J. Montreuil, G. Spik, Biochem. J. 312 (Pt 3) (1995) 839-845.

[34] P. Rossi, F. Giansanti, A. Boffi, M. Ajello, P. Valenti, E. Chiancone, G. Antonini, Biochem. Cell Biol. 80 (2002) 41-48 
[35] J.G. Fernandes, D.M. Correia, G. Botelho, J. Padrão, F. Dourado, C. Ribeiro, S. Lanceros-Méndez, V. Sencadas, Polym. Test. 34 (2014) 64-71.

[36] P. Gao, X. Nie, M. Zou, Y. Shi, G. Cheng, J. Antibiot. 64 (2011) 625-634.

[37] J. Quirós, J.P. Borges, K. Boltes, I. Rodea-Palomares, R. Rosal, J. Hazard. Mater. 299 (2015) 298-305

[38] J. Slane, J. Vivanco, W. Rose, H.L. Ploeg, M. Squire, Mater. Sci. Eng. C 48 (2015 $188-196$.

[39] X. Xu, M. Zhou, Fibers Polym. 9 (2008) 685-690.

[40] J. Wolfram, M. Zhu, Y. Yang, J. Shen, E. Gentile, D. Paolino, M. Fresta, G. Nie, C. Chen, H. Shen, M. Ferrari, Y. Zhao, Curr. Drug Targets 15 (2014) 1-11.

[41] D.M. Correia, J. Padrão, L.R. Rodrigues, F. Dourado, S. Lanceros-Méndez, V. Sencadas, Polym. Test. 32 (2013) 995-1000.

[42] H.Y. Cheung, M.R.W. Brown, J. Pharm. Pharmacol. 34 (1982) 211-214.

[43] L. Solorio, C. Zwolinski, A.W. Lund, M.J. Farrell, J.P. Stegemann, J. Tissue Eng. Regen. Med. 4 (2010) 514-523.

[44] Y. Yuan, B.M. Chesnutt, G. Utturkar, W.O. Haggard, Y. Yang, J.L. Ong, J.D Bumgardner, Carbohydr. Polym. 68 (2007) 561-567.

[45] L.-P. Yan, Y.-J. Wang, L. Ren, G. Wu, S.G. Caridade, J.-B. Fan, L.-Y. Wang, P.-H. Ji, J.M. Oliveira, J.T. Oliveira, J.F. Mano, R.L. Reis, J. Biomed. Mater. Res. A 95A (2010) 465-475.
[46] C.A. Schneider, W.S. Rasband, K.W. Eliceiri, Nat. Methods 9 (2012) 671-675

[47] AATCC, American Association of Textile Chemists and Colorists, North Carolina, 2012

[48] S. Ramakrishna, K. Fujihara, Wee-Eong Teo, T.-C. Lim, Z. Ma, An Introduction to Electrospinning and Nanofibers, World Scientific Publishing Co. Pte. Ltd, Singapore, 2005.

[49] J. Padrão, J.P. Silva, L.R. Rodrigues, F. Dourado, S. Lanceros-Méndez, V. Sencadas, Soft Mater. 12 (2014) 247-252.

[50] S. Gorgieva, V. Koko, Collagen- vs. gelatine-based biomaterials and their biocompatibility: review and perspectives, in: R. Pignatello (Ed.), Biomaterials Applications for Nanomedicine, InTech, 2011.

[51] S. Panprung, S. Apichart, S. Pitt, Nanotechnology 19 (2008) 015102.

[52] J.H. Muyonga, C.G.B. Cole, K.G. Duodu, Food Chem. 86 (2004) 325-332.

[53] K. Purna Sai, M. Babu, Comp. Biochem. Physiol. B: Biochem. Mol. Biol. 128 (2001) 81-90

[54] X. Yao, C. Bunt, J. Cornish, S.-Y. Quek, J. Wen, Chem. Biol. Drug Des. (2013), $\mathrm{n} / \mathrm{a}-\mathrm{n} / \mathrm{a}$.

[55] B.J. Nonnecke, K.L. Smith, J. Dairy Sci. 67 (1984) 606-613.

[56] M.M. Islam, A. Zaman, M.S. Islam, M. Khan, M. Rahman, Prog. Biomater. 3 (2014) 1-9. 